\title{
Article \\ Effect of Blanching on Enzyme Inactivation, Physicochemical Attributes and Antioxidant Capacity of Hot-Air Dried Pomegranate (Punica granatum L.) Arils (cv. Wonderful)
}

\author{
Adegoke Olusesan Adetoro ${ }^{1,2}$, Umezuruike Linus Opara ${ }^{2}$ and Olaniyi Amos Fawole ${ }^{3, *}$ \\ 1 Department of Horticultural Science, Stellenbosch University, Private Bag X1, Stellenbosch 7602, South Africa; \\ 21412944@sun.ac.za \\ 2 Postharvest Technology Research Laboratory, Africa Institute for Postharvest Technology, \\ Faculty of AgriSciences, Stellenbosch University, Private Bag X1, Stellenbosch 7602, South Africa; \\ opara@sun.ac.za \\ 3 Postharvest Research Laboratory, Department of Botany and Plant Biotechnology, \\ University of Johannesburg, P.O. Box 524, Auckland Park, Johannesburg 2006, South Africa \\ * Correspondence: olaniyif@uj.ac.za; Tel.: +27-11-559-7237; Fax: +27-11-559-2411
}

Citation: Adetoro, A.O.; Opara, U.L.; Fawole, O.A. Effect of Blanching on Enzyme Inactivation,

Physicochemical Attributes and Antioxidant Capacity of Hot-Air Dried Pomegranate (Punica granatum L.) Arils (cv. Wonderful). Processes 2021, 9, 25. https://dx.doi.org/ $10.3390 /$ pr 9010025

Received: 25 November 2020 Accepted: 21 December 2020 Published: 24 December 2020

Publisher's Note: MDPI stays neutral with regard to jurisdictional claims in published maps and institutional affiliations.

Copyright: () 2020 by the authors. Licensee MDPI, Basel, Switzerland. This article is an open access article distributed under the terms and conditions of the Creative Commons Attribution (CC BY) license (https://creativecommons.org/ licenses/by/4.0/).

\begin{abstract}
Blanch-assisted hot-air drying of pomegranate arils with blanching treatments $90{ }^{\circ} \mathrm{C}$ for $30 \mathrm{~s}, 100{ }^{\circ} \mathrm{C}$ for $60 \mathrm{~s}$, and unblanched (control) arils were investigated. Effects of blanching on enzyme inactivation (polyphenol oxidase and peroxidse), colour, texture, and other qualities of dried arils were discussed. The hot-air drying conditions were $60{ }^{\circ} \mathrm{C}, 19.6 \%$ relative humidity, and $1.0 \mathrm{~m} \mathrm{~s}^{-1}$ air velocity. Results showed that blanching reduced enzyme activity by $76 \%$ and $68 \%$ for blanched arils treated at $90{ }^{\circ} \mathrm{C}$ for $30 \mathrm{~s}$ and $100{ }^{\circ} \mathrm{C}$ for $60 \mathrm{~s}$, respectively, compared to unblanched arils. With regard to the total colour difference (TCD), unblanched arils were $20.9 \%$ and $16.6 \%$ higher than blanched arils treated at $90{ }^{\circ} \mathrm{C}$ for $30 \mathrm{~s}$ and $100{ }^{\circ} \mathrm{C}$ for $60 \mathrm{~s}$, respectively. Furthermore, the total soluble solids (TSS) for unblanched aril increased significantly from 16.1 to $24.9^{\circ}$ Brix after drying, followed by arils treated at $90^{\circ} \mathrm{C}$ for $30 \mathrm{~s}$ and $100^{\circ} \mathrm{C}$ for $60 \mathrm{~s}\left(21.4 ; 18.5^{\circ}\right.$ Brix $)$, respectively. Among the blanching treatments, dried arils treated at $90^{\circ} \mathrm{C}$ for $30 \mathrm{~s}$ had the highest total anthocyanin content (28.6 mg C3gE/g DM), followed by $100{ }^{\circ} \mathrm{C}$ for $60 \mathrm{~s}$ (24.8 mg C3gE/g DM). Similarly, dried arils treated at $90{ }^{\circ} \mathrm{C}$ for $30 \mathrm{~s}$ had the highest radical scavenging activity (RSA) (32.1 mM TE/g DM) while the least was observed with unblanched arils (17.0 mM TE/g DM). Overall, the blanching treatment was more effective to maintain the quality attributes of pomegranate dried arils.
\end{abstract}

Keywords: peroxidase; colour; texture; rehydration; antioxidants; PCA

\section{Introduction}

Pomegranate (Punica granatum L.) is a fruit grown in the tropical and subtropical region of the world, including Asia, USA, Russia, North Africa, and Spain [1-3]. In the past five years, South Africa has increased its commercial production, accounting for approximately 1.4 million cartons exported in 2017 compared to about 400,000 cartons exported in 2012 [4]. Considering the high nutritional and polyphenolic properties in pomegranate, consumers have consciously shifted their interest towards the fruit due to the continuous increase in its consumption [5]. The fruit comprises of a non-edible (peel) and the edible portion (arils), the arils contain juice and seed/kernel, with the arils arranged in sac-like structure compartments $[5,6]$. These have been identified as a potential product of functional food with a high level of biochemical compounds as well as reported health benefits such as antioxidants, antimicrobial and anti-inflammatory activities [7-9]. Its consumption is eminently taken as juice and is used largely in the industry to manufacture food-related materials, such as jellies, jams, flavouring and colouring agents [10].

Several metabolic activities occur during fruit development which results in significant changes in the visual and organoleptic properties of the fruit, reducing the marketability 
of the harvested product [11]. Further, quality reduction and postharvest losses during handling and storage results mostly from the initial damages found on the fruit $[12,13]$. Mechanical damages including cracks, bruises, as well as fruit discolouration resulting from black spots results in high harvest and postharvest losses. For instance, fruit cracking alone could result in 20-40\% loss in fruits [14], and hence loss of income, as cracked rarely fetch reasonable prices. In addition, pomegranate arils are highly perishable with very short shelf-life [6]. This limits its availability in the market during the offseason period. Drying is a useful means to extend the shelf-life of the fruit and its co-products, such as arils [15]. It involves the use of heat to vaporize the water present in the food, as well as protect food from adverse effects of microbial and enzymatic activities [15-17]. This enables food products to be stored for more extended periods since the activities of microorganisms and enzymes are inhibited through the thermal process. Thermal processing affects food-value compounds such as pigments, anthocyanin, and phenolic compounds [18,19]. Moreover, fruit-cut before drying also causes colour degradation due to browning pigmentation. Enzymes such as polyphenol oxidase and peroxidase are responsible for these activities. They oxidize mono- and di-phenols to form o-quinones which appears as brown pigments [20-24].

Pomegranate arils have a problem of low quality in part due to discolouration (enzymatic browning) during handling and storage, and as a result, it commands a low premium in the market [21]. Due to the high moisture content in pomegranate arils (between 50 to $80 \%$ wet basis), an extended drying period is often required, which often reduces the sensory quality (taste and texture) and antioxidant properties of the dried product. Therefore, it is very crucial to address such quality deteriorating factors to enhance the marketability of the dried product. One of the common ways to reduce the process of enzymatic browning in a food material is by inhibiting the activity of the enzymes through pretreatment [25]. Several pretreatment methods can be applied depending on the food material to be dried, its end product, and availability [26]. Many studies have reported the successful application of pretreatments such as water blanching, steam blanching, sulphiting, citric and ascorbic acid in its application to control enzymatic browning $[21,24,27]$. Blanching is one of the pretreatment methods often used to inhibit physiological and biochemical processes before drying of minimally processed vegetables and fruits. In particular, heat pretreatment is known to inactivate the enzymes causing the unacceptable discolouration in dried horticultural products [26]; it further stabilizes bioactive compounds during processing and storage [28]. The process of blanching involves heating the food materials with steam or hot water before drying [29]. Maghoumi et al. [30] reported the use of hot water dipping on pomegranate arils heated at $55^{\circ} \mathrm{C}$ for $30 \mathrm{~s}$ and observed that hot water suppressed the polyphenol oxidase activity. Similarly, Thakur et al. [21] investigated steam blanching pretreatment to prevent the discolouration of dried arils, and reported that pretreated samples had highest scores for sensory characteristics such as colour, texture, taste, aroma, and overall acceptability. Blanching also significantly decreased the colour chroma of Ziziphus mauritiana fruits in comparison with non-blanched fruits [25].

Wonderful pomegranate cultivar is one of the most popularly consumed and exported pomegranate cultivars in South Africa. In a quest to add value to the fruit through agro-processing into high quality dried arils, this experiment was conducted. Therefore, the objectives of this study were (i) to investigate the effect of blanching pretreatment on enzymes inactivation of pomegranate arils; (ii) to quantify the impact of blanching on the quality attributes of pomegranate arils $\mathrm{cv}$. Wonderful.

\section{Materials and Methods}

\subsection{Fruit Material and Processing}

Pomegranate fruit (cv. Wonderful) were harvested at commercial maturity from Blydeverwacht orchard, Wellington, South Africa $\left(33^{\circ} 01^{\prime} 00^{\prime \prime} \mathrm{S}, 18^{\circ} 58^{\prime} 59^{\prime \prime} \mathrm{E}\right)$. Fruit were sorted into categories such as size, shape, and colour uniformity and after which were transported 
in an air-conditioned vehicle to the Postharvest Technology Laboratory at Stellenbosch University. Pomegranate arils were carefully extracted and used for immediate processing. Ten grams of pomegranate arils was taken for initial moisture content determination using a moisture analyzer (KERN DBS 60-3 Balingen, Germany) [31]. The initial moisture content of the fresh arils was $78.56 \%$ (w.b.).

\section{Aril Drying Procedure}

In batches, blanching of fresh arils was carried out in a laboratory-sized-water bath. Arils were blanched at $90^{\circ} \mathrm{C}$ for $30 \mathrm{~s}$ and $100{ }^{\circ} \mathrm{C}$ for $60 \mathrm{~s}$. Unblanched arils were used as the control. Blanched arils were subjected to dipping in iced water at $0{ }^{\circ} \mathrm{C}$ for $3 \mathrm{~min}$ to discontinue the heating process. The arils were carefully drained prior to being weighed. The process was carried out three times for each treatment. Arils $(60 \mathrm{~g})$ was weighed before subjected to drying in an oven (Model nr. 072160, Prolab Instruments, Sep. Sci., Johannesburg, South Africa) set at $60^{\circ} \mathrm{C}, 19.6 \%$ relative humidity (RH) until the desired moisture content between 10-12 $\pm 0.2 \%$ wet basis (w.b.) was reached. The constant air velocity of the oven was $1.0 \mathrm{~m} \mathrm{~s}^{-1}$ and ambient air at $20 \pm 0.3{ }^{\circ} \mathrm{C}$ and $80-88 \% \mathrm{RH}$. Detailed information on aril drying characteristics of blanched-assisted pomegranate arils was discussed in our previous study [27].

\subsection{Enzyme Extraction}

Polyphenol oxidase (PPO) and peroxidase (POD) extractions were carried out using a modified method described by Jiang [32]. Dried pomegranate aril (1 g) was grounded into powder and mixed with $10 \mathrm{~mL}$ extraction solution $(0.1 \mathrm{M}$ phosphate buffer at $\mathrm{pH} 7$, $0.05 \mathrm{M} \mathrm{L}^{-1}$ EDTA and $60 \mathrm{~g} \mathrm{~L}^{-1}$ polyvinyl polypyrrolidone). The mixture was continuously stirred for $5 \mathrm{~min}$ and kept at $4{ }^{\circ} \mathrm{C}$ for $2 \mathrm{~h}$. The mixture was subjected to centrifugation process at $12,298 \times g$ force for $25 \mathrm{~min}$ at $4{ }^{\circ} \mathrm{C}$ before the supernatant was carefully collected and filtered through a $0.45-\mu \mathrm{m}$ filter membrane. The supernatant was used as crude enzyme extract.

\subsubsection{Polyphenol Oxidase (PPO) Activity Determination}

PPO activity was carried out according to Meighani et al. [22] with minor modifications. The crude enzymes extract $(0.2 \mathrm{~mL})$ was added to $300 \mu \mathrm{L}(0.1 \mathrm{M})$ catechol and $2.5 \mathrm{~mL}$ of $0.1 \mathrm{M}$ potassium phosphate buffer ( $\mathrm{pH} 6.0)$. For $6 \mathrm{~min}$ at $25^{\circ} \mathrm{C}$, the absorbance $(420 \mathrm{~nm})$ was continuously recorded with the use of UV-visible spectrophotometer (Thermo Scientific Technologies, Madison, WI, USA). Without the enzyme extract, the blank cuvette contained the extraction solution. One unit of enzyme activity $(\mathrm{U} / \mathrm{min} / \mathrm{mL})$ was referred to as the amount of enzyme that resulted in a change of 0.001 in absorbance unit per minute under the conditions of the PPO assay [24].

\subsubsection{Peroxidase Activity (POD) Activity Determination}

POD activity was carried out using a spectrophotometric method using UV-visible spectrophotometer (Thermo Scientific Technologies, Madison, WI, USA) at $470 \mathrm{~nm}$ absorbance. The phenolic substrates used were Guaiacol and hydrogen peroxide as described by Shah et al. [33] with minor modification. The reaction mixture contained $0.1 \mathrm{~mL}$ of $0.045 \mathrm{M}$ guaiacol, $0.15 \mathrm{~mL}$ of $0.225 \mathrm{M} \mathrm{H}_{2} \mathrm{O}_{2}, 2.73 \mathrm{~mL}$ of $0.1 \mathrm{M}$ phosphate buffer $\mathrm{pH} 6$ and $20 \mu \mathrm{L}$ of the crude enzyme extract. The blank sample contained the same mixture solution without the enzyme extract. The quantity of enzyme causing a change of 0.001 in absorbance unit per minute under the conditions of the POD assay was indicated as one unit of enzyme activity $(\mathrm{U} / \mathrm{min} / \mathrm{mL})$.

The residual enzyme activity (REA) gives information about the total reduction of enzyme activity caused by a heat process. PPO and POD enzymes inactivation were evaluated by exposing these enzymes to two blanching treatments and further subjected to the same condition of drying. The outcome of the REA described for POD and PPO was given in percentage relative activity. The rate of actual and residual activities was 
measured in a given time interval. According to Sarpong et al. [24], the residual enzyme activity was expressed as:

$$
\text { REA }(\%)=\frac{\text { Current enzyme activity }}{\text { Initial enzyme activity }} \times 100
$$

\subsection{Measurement of Physical Properties of Arils \\ 2.3.1. Aril Colour}

Aril colour was measured by reading directly from a chromo-meter (Minolta model CR-200, Osaka, Japan) to capture the values of the following colour parameters: $L^{*}$ (brightness/darkness), $a^{*}$ (redness/greenness), and $b^{*}$ (yellowness/blueness). Colour parameters, including chroma $C^{*}$, hue angle $h^{\circ}$ and total colour difference (TCD) were calculated according to Pathare et al. [34] and Fawole and Opara [5].

$$
\begin{gathered}
C^{*}=\left(a^{* 2}+b^{* 2}\right)^{1 / 2} \\
h^{\circ}=\tan ^{-1}\left(b^{*} / a^{*}\right) \\
\mathrm{TCD}=\left[\left(\Delta L^{*}\right)^{2}+\left(\Delta a^{*}\right)^{2}+\left(\Delta b^{*}\right)^{2}\right]^{\frac{1}{2}}
\end{gathered}
$$

where $\Delta L^{*}, \Delta a^{*}$, and $\Delta b^{*}$ referred to the differences between the colour of the fresh and blanch-assisted dried arils at each treatment levels and carried out in triplicate. Results were presented as means \pm S.E.

\subsubsection{Aril Texture}

The texture of dried pomegranate arils was evaluated using a texture analyzer (TA. XT-Plus, Stable Microsystems Ltd., Surrey, UK), with a $35 \mathrm{~mm}$ diameter cylindrical compression probe $[35,36]$. Individual arils were subjected to compression test and the maximum compression force to rupture each aril with a pre-test speed $1.5 \mathrm{~mm} / \mathrm{s}$, probe test speed $1 \mathrm{~mm} / \mathrm{s}$ and post-test speed $10.0 \mathrm{~mm} / \mathrm{s}$ was $10 \mathrm{~N}$. Also, the compression distance was $10 \mathrm{~mm}$. The data observed from the texture analyzer was interpreted using software Exponent v.4 (Stable Micro System Ltd., Surrey, UK). The software was used to run macro which gave the Hardness $(\mathrm{H})$; positive force $(\mathrm{N})$ measured during compression and Stickiness $\left(\mathrm{S}_{\mathrm{k}}\right)$; negative force $(-\mathrm{N})$ taken before return to the initial position. A dried aril compression test was carried out on 10 randomly selected aril for each drying method, and the results were presented as mean \pm S.E.

\subsubsection{Rehydration Capacity}

Rehydration experiments were investigated according to Giri and Prasad [37]. A $10 \mathrm{~g}$ of dried aril samples were soaked into distilled hot water at $50{ }^{\circ} \mathrm{C}$. At $30 \mathrm{~min}$ intervals, the samples were removed, drained with a laboratory mesh and placed on a five-layer paper towel. Samples were blotted for about $30 \mathrm{~s}$ in order to remove the surface water by softly adjusting the arils on the towel and then weighed to an exact value $(0.0001 \mathrm{~g})$. The rehydration capacity described the ratio of the weight of rehydrated samples to the dry weight of the sample was calculated (Equation (5))

$$
\text { Rehydration ratio }=\frac{W_{t}}{W_{d}}
$$

where, $W_{t}$ is the weight of wet arils at time $(t)$, while $W_{d}$ is the initial weight of dry arils.

\subsection{Extraction of Samples}

With the use of liquid nitrogen, dried pomegranate arils were ground into powder afterwards, extraction of $5 \mathrm{~g}$ sample in $50 \mathrm{~mL}$ distilled water. The mixture was vortexed for $5 \mathrm{~min}$, followed by sonication in an ultrasonic bath for $15 \mathrm{~min}$ and subsequently centrifuging the mixture for $25 \mathrm{~min}$ at $12,298 \times \mathrm{g}$ force. The recovery of the supernatant 
was used for analyses including TSS, TA and $\mathrm{pH}$ measurements. The same procedure was followed for phenolic content and antioxidant capacity, using $50 \%$ methanol.

\subsection{Determination of Total Soluble Solids (TSS), Titratable Acidity (TA) and $p H$}

TSS was taken with a digital hand refractometer (model PT-32; ATAGO, Tokyo, Japan) with a range between $0-32{ }^{\circ}$ Brix which was blanked with distilled water. For TA, $2 \mathrm{~mL}$ of supernatant was diluted in $70 \mathrm{~mL}$ of distilled water and titrated against $0.2 \mathrm{~N}$ of sodium hydroxide $(\mathrm{NaOH})$ to a $\mathrm{pH}$ of 8.2 using a Metrohm 862 Compact titrosampler (Herisau, Switzerland). BrimA index, a variant of TSS/TA and a measure for fruit taste acceptance, which is expressed as BrimA $=$ TSS $-k \times \mathrm{TA}$, where $k$ is the tongue's sensitivity index normally ranging from 2-10 [8]. In this study $k$ value of 2 was used to avoid negative BrimA index. The value of $\mathrm{pH}$ of dried pomegranate aril was taken with the use of a $\mathrm{pH}$ meter (Crison, Barcelona, Spain).

\subsection{Phytochemical Properties and Antioxidant Activity}

\subsubsection{Determination of Total Phenolic Content}

Total phenolic content (TPC) of dried pomegranate arils was quantified according to the Folin-Ciocalteu method using a methanolic extract of dried arils. A $0.05 \mathrm{~mL}$ of the supernatant was mixed with $0.45 \mathrm{~mL}$ of $50 \%$ methanol in a test tube. After $2 \mathrm{~min}$, Folin-Ciocalteu $(0.5 \mathrm{~mL})$ was added into the mixture and vortexed. The mixture was kept in the dark for $10 \mathrm{~min}$ followed by adding $2 \% \mathrm{Na}_{2} \mathrm{CO}_{3}$ before incubating in the dark for $40 \mathrm{~min}$. The absorbance of each sample was read at $750 \mathrm{~nm}$ in a UV-visible spectrophotometer (Thermo Scientific technologies, Madison, WI, USA) against a blank containing 50\% methanol. A standard curve consisting of gallic acid, $0-10 \mathrm{mg}$ was used, and results were presented as $\mathrm{mg}$ gallic acid equivalent per gram pomegranate dry matter (mg GAE/g DM).

\subsubsection{Total Anthocyanin Content}

Total anthocyanin content (TAC) was determined according to $\mathrm{pH}$ differential method [38]. Extract $(1 \mathrm{~mL})$ was mixed with $9 \mathrm{~mL}$ of $p H 1.0$ and $p H 4.5$ buffers separately while replicated three times. Absorbance was measured at 510 and $700 \mathrm{~nm}$ in $\mathrm{pH} 1.0$ and 4.5 buffers, and the result was presented as cyanidin 3-glucoside using Equation (6).

$$
\begin{gathered}
\qquad A=\left(A_{510}-A_{700}\right)_{p H 1.0}-\left(A_{510}-A_{700}\right)_{p H 4} \\
\text { Total monomeric anthocyanin }(\mathrm{mg} / \mathrm{mL})=\frac{A \times M W \times D F}{\varepsilon \times L}
\end{gathered}
$$

where $A=$ Absorbance, $\varepsilon=$ Cyd-3-glucoside molar absorbance $(26,900), M W=$ anthocyanin molecular weight (449.2), $D F=$ dilution factor, and $L=$ cell path length $(1 \mathrm{~cm})$. Final results are presented as equivalent per gram dry matter (mg C3gE/g DM).

\subsubsection{Radical-Scavenging Activity}

Radical scavenging activity (RSA) was determined in triplicate, according to Fawole and Opara [5]. Briefly, under dim light, $0.0150 \mathrm{~mL}$ aqueous methanolic extract of dried aril was placed in a test tube and diluted with $0.735 \mathrm{~mL}$ methanol after which $0.75 \mathrm{~mL}, 0.1 \mathrm{mM}$ methanolic DPPH solution was added. For $30 \mathrm{~min}$, the mixtures were incubated at room temperature in the dark while the absorbance was measured at $517 \mathrm{~nm}$ using a UV-vis spectrophotometer. Absorbance was compared with the standard curve (Trolox equivalent, $0-2.0 \mathrm{mM})$. The free-radical activity of dried aril was presented as Trolox equivalent $(\mathrm{mM})$ equivalent per gram dry matter (mM TE/g DM).

\subsubsection{Ferric Ion Reducing Antioxidant Power (FRAP)}

According to Benzie and Strain [39], the antioxidant power of dried aril was measured calorimetrically as the FRAP working solution was freshly prepared in mixtures of $300 \mathrm{mM}$ 
acetate buffer $(50 \mathrm{~mL})$, followed by the addition of $10 \mathrm{mM}$ 2,4,6-tripyridyl-s-triazine (TPTZ) $(5 \mathrm{~mL})$ and $20 \mathrm{mM}$ ferric chloride $(5 \mathrm{~mL})$ at $37^{\circ} \mathrm{C}$. In triplicates, the mixture of $0.15 \mathrm{~mL}$ diluted aqueous methanolic dried aril extracts $(0.15 \mathrm{~mL})$ with $2.85 \mathrm{~mL}$ of the FRAP working solution was carried out before incubation in the dark for $30 \mathrm{~min}$. The procedure was carried out in triplicate as the reduction of the $\mathrm{Fe}^{3+}-\mathrm{TPTZ}$ complex to a coloured $\mathrm{Fe}^{2+}-\mathrm{TPTZ}$ was monitored by measuring the absorbance at $593 \mathrm{~nm}$ at low $\mathrm{pH}$ by dried aril extracts. Trolox equivalent ranging from 0 to $10 \mathrm{mM}$ was used for the calibration curve, while the results were presented as Trolox (mM) equivalents per gram dry matter (mM TE/g DM).

\subsection{Statistical Analysis}

The analyses made from the physicochemical and phytochemical properties were evaluated statistically. Data were analysed using STATISTICA (Statistica 13.0, StatSoft Inc., Tulsa, OK, USA) and expressed as mean \pm standard error. All analyses were replicated three times. Data was subjected to analysis of variance (ANOVA), and means were separated at a level of significance of 95\% confidence level according to Fisher's LSD test. GraphPad Prism software 4.03 (GraphPad Software, Inc., San Diego, CA, USA) was used for graphical presentations. XLSTAT software version 2012.04.1 (Addinsoft, France) was used to generate the principal component analysis (PCA).

\section{Results}

\subsection{Influence of Blanching on Enzymes Inactivation}

The result of blanching on the polyphenol oxidase and peroxidase are presented in Figure 1. A significant $(p<0.05)$ difference was observed among the blanching conditions for the residual PPO activity (Figure 1a). Blanching reduced the effect of enzyme activity by 76 and $68 \%$ for both blanching treatment at $90^{\circ} \mathrm{C}$ for $30 \mathrm{~s}$ and $100{ }^{\circ} \mathrm{C}$ for $60 \mathrm{~s}$, respectively, compared to unblanched arils with the highest value of residual enzyme activity.

Similarly, POD inactivation was significantly $(p<0.05)$ different among blanching treatments (Figure 1b). Unblanched arils had the highest residual POD activity (14.9\%), followed by $100{ }^{\circ} \mathrm{C} 60 \mathrm{~s}(3.52 \%)$, while arils blanched at $90{ }^{\circ} \mathrm{C} 30 \mathrm{~s}$ had the least value $(1.25 \%)$. The trend observed for both residual enzyme activity (PPO and POD) was more effective for blanched arils treated at $90{ }^{\circ} \mathrm{C}$ for $30 \mathrm{~s}$ and $100{ }^{\circ} \mathrm{C} 60 \mathrm{~s}$. This could be related to a higher blanching temperature $\left(90\right.$ and $\left.100{ }^{\circ} \mathrm{C}\right)$ and exposure time (30 and $\left.60 \mathrm{~s}\right)$ which is known to reduce enzyme activity in pomegranate arils. The synergistic effect of pretreatment and drying was observed to reduce enzyme activities in banana slices due to higher temperature [24]. A similar result was observed in this study, where both blanching treatments $\left(90^{\circ} \mathrm{C}\right.$ for $30 \mathrm{~s}$ and $100{ }^{\circ} \mathrm{C}$ for $\left.60 \mathrm{~s}\right)$ reduced enzyme activity. The mechanism to the result was reported by Jaiswal et al. [40]. The authors noted that in pretreated food materials, quinones are formed from phenolic compounds due to enzyme inactivation as a result of the presence of hydrogen peroxide appearing in a low peroxidase level.

\subsection{Colour Change}

Blanching retained the colour attributes of dried pomegranate arils significantly $(p<0.05)$. From Table 1 , blanched arils at both $90{ }^{\circ} \mathrm{C}$ for $30 \mathrm{~s}(26.5)$ and $100{ }^{\circ} \mathrm{C}$ for $60 \mathrm{~s}(24.6)$ had better retention of lightness $\left(L^{*}\right)$ with closer values to the fresh arils (29.4) compared to unblanched dried arils (21.4). The blanched arils at $90^{\circ} \mathrm{C}$ for $30 \mathrm{~s}$ and $100{ }^{\circ} \mathrm{C}$ for $60 \mathrm{~s}$ were 9.8 and $16.3 \%$ darker, respectively than the fresh arils, while unblanched arils $(27 \%)$ darker than the fresh arils. For pomegranate dried aril redness $\left(a^{*}\right)$, blanched arils at $90{ }^{\circ} \mathrm{C}$ for $30 \mathrm{~s}$ and $100{ }^{\circ} \mathrm{C}$ for $60 \mathrm{~s}$ had significantly lower values (17.6 and 18.4), respectively, compared to unblanched arils (20.4). This also suggests that blanched arils maintained the red colour of dried arils compared to fresh arils. This may be an indication that blanching helps retains anthocyanin pigments, thereby reducing browning [28]. Also, the reduction in enzymatic activity (PPO and POD) in blanched arils (Figure 1) could be related to the retention of the red colour attribute in dried pomegranate arils. The significant increase in $a^{*}$ value for the unblanched arils was expected. This could, in part, be due to pigment instability with 
regards to high sensitivity of fruit to heat application or enzymatic browning reaction or both during dehydration [41,42].

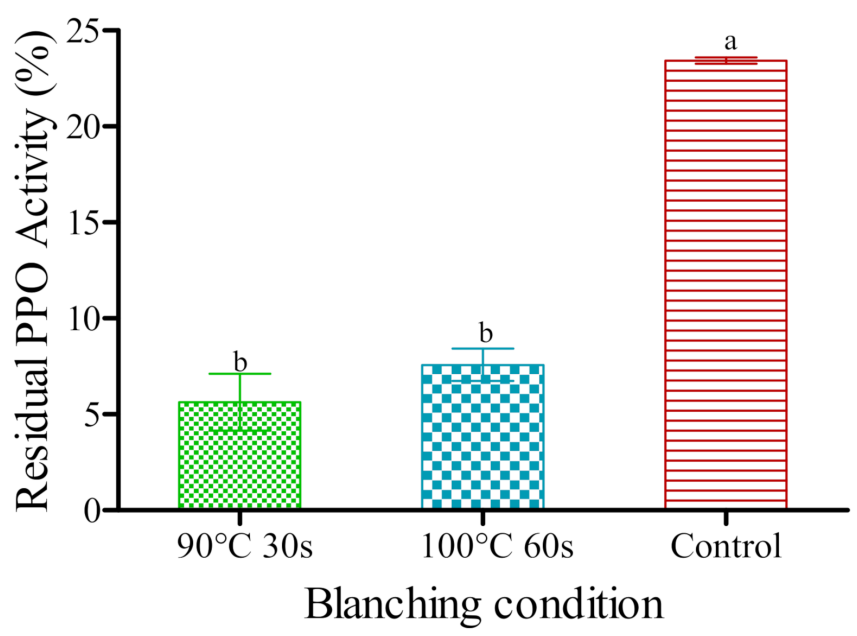

(a)

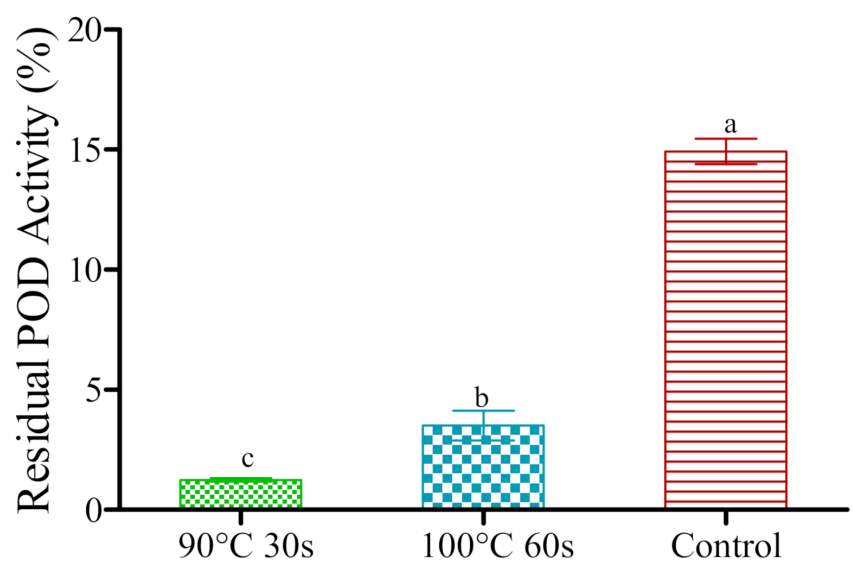

Blanching condition

(b)

Figure 1. Effects of blanching conditions on the residual (a) polyphenol oxidase (PPO) and (b) peroxidase (POD) of dried pomegranate aril cv. Wonderful. (Data presented as means \pm SE. Bars followed by different letter(s) are significantly different $(p<0.05)$ according to Fisher's LSD).

Table 1. Changes in colour attributes of fresh and dried pomegranate arils for different blanching conditions.

\begin{tabular}{cccccc}
\hline $\begin{array}{c}\text { Blanching } \\
\text { Condition }\end{array}$ & $\boldsymbol{L}^{*}$ & $\boldsymbol{a}^{*}$ & $\boldsymbol{C}^{*}$ & $\boldsymbol{h}^{\circ}$ & TCD \\
\hline Fresh & $29.4 \pm 0.06^{\mathrm{a}}$ & $18.4 \pm 0.25^{\mathrm{b}}$ & $21.2 \pm 0.22^{\mathrm{a}}$ & $29.8 \pm 1.51^{\mathrm{a}}$ & - \\
Control & $21.4 \pm 0.08^{\mathrm{c}}$ & $20.4 \pm 0.08^{\mathrm{a}}$ & $22.0 \pm 0.02^{\mathrm{a}}$ & $21.9 \pm 0.63^{\mathrm{b}}$ & $8.56 \pm 0.16^{\mathrm{a}}$ \\
$90^{\circ} \mathrm{C} 30 \mathrm{~s}$ & $26.5 \pm 0.67^{\mathrm{b}}$ & $17.6 \pm 0.81^{\mathrm{b}}$ & $18.2 \pm 0.85^{\mathrm{b}}$ & $14.7 \pm 1.37^{\mathrm{c}}$ & $6.77 \pm 0.68^{\mathrm{b}}$ \\
$100^{\circ} \mathrm{C} 60 \mathrm{~s}$ & $24.6 \pm 0.56^{\mathrm{b}}$ & $18.4 \pm 0.19^{\mathrm{b}}$ & $18.9 \pm 0.14^{\mathrm{b}}$ & $13.6 \pm 1.83^{\mathrm{c}}$ & $7.14 \pm 0.10^{\mathrm{b}}$ \\
\hline
\end{tabular}

$L^{*}$; lightness, $a^{*}$; redness, $C^{*}$; chroma, $h^{\circ}$ hue angle, TCD; total colour difference. Data presented as means \pm SE in each column followed by different letters are significantly different $(p<0.05)$ according to Fisher's LSD.

The chroma $\left(C^{*}\right)$ of dried pomegranate arils showed the degree of colour intensity. Blanched arils at $90^{\circ} \mathrm{C}$ for $30 \mathrm{~s}$ and $100^{\circ} \mathrm{C}$ for $60 \mathrm{~s}$ had the lowest values for colour intensity 
(18.2 and 18.9), respectively, compared to the unblanched arils (22.0) Table 1. This implies that $C^{*}$ contributed to the degree of redness of dried arils for both blanched arils $90^{\circ} \mathrm{C}$ for $30 \mathrm{~s}$ and $100{ }^{\circ} \mathrm{C}$ for $60 \mathrm{~s}$. Further, the process of enzyme inactivation as a result of blanching contributed to retaining the colour intensity of dried arils. Our results agreed with Deylami et al. [28], who reported high retention in $\mathrm{a}^{*}$ and $C^{*}$ of blanched mangosteen due to PPO inactivation. Similarly, hue angle showed the highest values for fresh arils followed by the unblanched arils, while $90^{\circ} \mathrm{C}$ for $30 \mathrm{~s}$ and $100^{\circ} \mathrm{C}$ for $60 \mathrm{~s}$ had the lowest hue values. The decreased hue angle values after hot-air drying indicated that the colour of blanched-assisted dried aril samples did not lose redness as much as unblanched (control) sample [43]. Colour retention is known as one of the quality indicators to assess the magnitude of deterioration due to thermal processing [44]. The total colour difference (TCD) was significantly higher for unblanched arils (8.56) compared to $90^{\circ} \mathrm{C} 30 \mathrm{~s} \mathrm{(6.77)}$ and $100{ }^{\circ} \mathrm{C} 60 \mathrm{~s}$ (7.14) (Table 1). This implies that blanched arils at $90{ }^{\circ} \mathrm{C}$ for $30 \mathrm{~s}$ and $100{ }^{\circ} \mathrm{C}$ for $60 \mathrm{~s}$ in this study had a better appearance considering the lower TCD values than the unblanched arils. Colour is a significant parameter that affects the marketability and consumer preference of fruit $[10,45,46]$ as blanched arils would be more preferred than the unblanched arils.

\subsection{Textural Properties}

Dried aril hardness increased with or without blanching as presented in Table 2, indicating that the amount of force used to compress unblanched dried arils was similar to that of blanched arils.

Table 2. Changes in the hardness and stickiness of dried pomegranate arils for different blanching conditions.

\begin{tabular}{ccc}
\hline Blanching Condition & Hardness $\mathbf{( N )}$ & Stickiness $\mathbf{( - N )}$ \\
\hline Fresh & $117.1 \pm 1.09^{\mathrm{b}}$ & - \\
Control & $5633.1 \pm 233.8^{\mathrm{a}}$ & $-46.8 \pm 3.68^{\mathrm{c}}$ \\
$90^{\circ} \mathrm{C} 30 \mathrm{~s}$ & $5448.9 \pm 221.1^{\mathrm{a}}$ & $-35.1 \pm 4.21^{\mathrm{b}}$ \\
$100^{\circ} \mathrm{C} 60 \mathrm{~s}$ & $5339.7 \pm 209.1^{\mathrm{a}}$ & $-23.3 \pm 2.69^{\mathrm{a}}$ \\
\hline
\end{tabular}

Data presented as means \pm SE in each column followed by different letters are significantly different $(p<0.05)$ according to Fisher's LSD.

Arils blanched at $90^{\circ} \mathrm{C}$ for $30 \mathrm{~s}$, and $100{ }^{\circ} \mathrm{C}$ for $60 \mathrm{~s}$ had lower values of hardness (5448.9 and $5339.7 \mathrm{~N})$, respectively than unblanched arils (5633.1 N). Differences in the values of hardness between unblanched and blanched arils could partly, be due to the rate at which moisture evaporated from the arils or increased concentration of solids in the arils after drying contributing to the mechanical strength of the albedo (seed). Overall hardness in dried arils after processing suggests that dried arils were not affected by blanching. Results from our study are in contrast to those reported by Beveridge and Weintraub [47], who observed an increase of hardness in red apple slices after the blanching treatment.

Furthermore, the force required for the stickiness of blanched arils to return to its initial position was significantly $(p<0.05)$ different from the unblanched aril (Table 2$)$. The force required for the stickiness of blanched arils decreased with increase in temperature and extended time. For instance, blanching at $100^{\circ} \mathrm{C}$ for $60 \mathrm{~s}$ was less sticky $(-23.3 \mathrm{~N})$ than $90^{\circ} \mathrm{C}$ for $30 \mathrm{~s}(-35.1 \mathrm{~N})$. This observation indicated that temperature $\left(90\right.$ and $\left.100^{\circ} \mathrm{C}\right)$ and extended time (30 and $60 \mathrm{~s}$ ) during blanching results in an increase in dried aril stickiness. However, unblanched arils were stickier $(-46.8 \mathrm{~N})$ than the blanched arils. The textural dynamics shown in the sticky product could be as a result of high sugar content observed around the dried arils after thermal treatment.

\subsection{Rehydration Capacity}

Rehydration is a measure of sensorial properties [44]. It expresses the physicochemical changes during drying as influenced by processing conditions and pretreated samples [48]. 
Figure 2 shows that the rehydration capacity of dried pomegranate aril was affected by blanching condition.

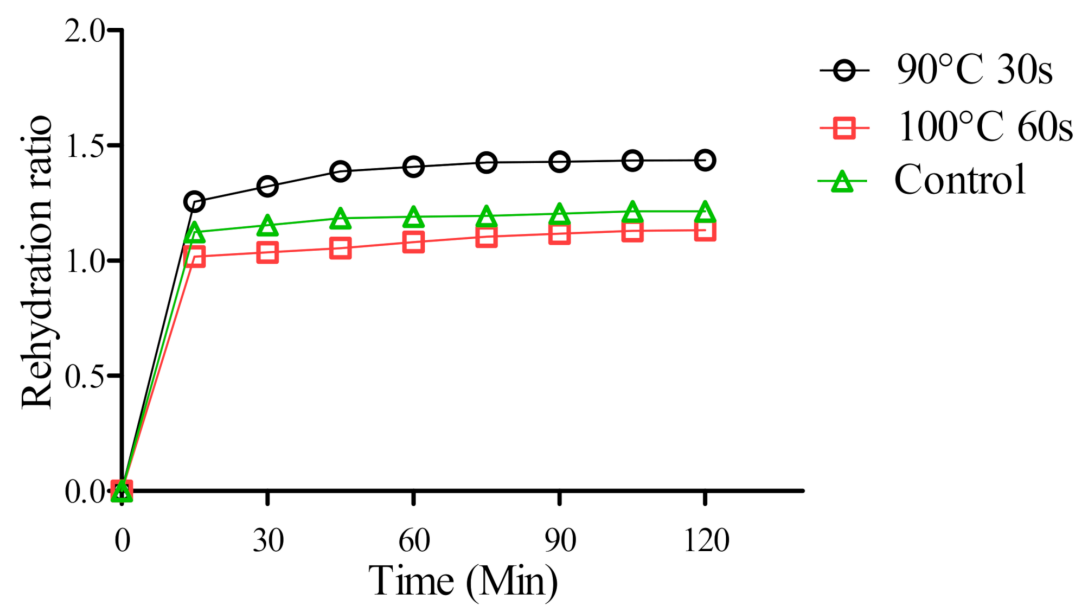

Figure 2. Rehydration behaviour of dried pomegranate arils at different blanching conditions.

In general, faster water absorption was noticed at the commencement of the process and continued at a constant rate before the maximum capacity was reached. Aril sample blanched at $90{ }^{\circ} \mathrm{C}$ for $30 \mathrm{~s}$ had the highest rehydration rate (1.49), followed by unblanched arils (1.28), while dried aril sample at $100{ }^{\circ} \mathrm{C}$ for $60 \mathrm{~s}$ had the lowest rehydration rate (1.20). Both blanched and unblanched aril samples could not acquire the same amount of moisture as contained when fresh. This suggests that cellular and structural destruction occurred during drying, and the degree of damage is mainly determined by the blanching condition. Decreased rehydration capacity observed in the aril sample blanched at $100{ }^{\circ} \mathrm{C}$ for $60 \mathrm{~s}$ could be attributed to higher temperature the arils were subjected to during blanching. Vega-Galvez et al. [42] and Horuz and Maskan [44] reported severe shrinkage and tissue breakdown due to higher temperatures resulting in a decrease in rehydration capacity. This phenomenon could be explained as higher temperature causing irreversible cellular rupture, which disallows imbibition due to high shrunken capillaries with reduced hydrophilic properties.

\subsection{Total Soluble Solids (TSS), Titratable Acidity (TA) and $p H$}

Chemical properties, such as TSS, TA, and TSS/TA, have been used to describe taste (flavour) with regards to the sweetness and acidity; these properties have also been used as a quality criterion for the formulation of pomegranate products [1]. As shown in Table 3, all chemical properties measured for dried pomegranate arils significantly $(p<0.05)$ increased by blanching treatment. TSS increased from $16.1^{\circ}$ Brix to $24.9^{\circ}$ Brix for unblanched arils after drying, followed by blanched arils at $90^{\circ} \mathrm{C}$ for $30 \mathrm{~s}\left(21.4{ }^{\circ} \mathrm{Brix}\right)$. The least TSS amongst the treated arils was recorded for arils blanched at $100^{\circ} \mathrm{C}$ for $60 \mathrm{~s}\left(18.5^{\circ} \mathrm{Brix}\right)$. In other words, a lower temperature $\left(90^{\circ} \mathrm{C}\right)$ and exposure time $(30 \mathrm{~s})$ resulted in higher total soluble content compared to arils treated at higher temperature and time of $100{ }^{\circ} \mathrm{C}$ for $60 \mathrm{~s}$. This could be as a result of leaching during the blanching process, which could be more at a higher temperature $\left(100^{\circ} \mathrm{C}\right)$ and a longer time of exposure $(60 \mathrm{~s})$. However, the significant increase in TSS for the unblanched arils could be attributed to the fact that there was no pretreatment at any stage before drying. Hence, soluble solids within the aril sac were tightly packed together. 
Table 3. Chemical attributes of fresh and dried pomegranate arils with different blanching conditions.

\begin{tabular}{cccccc}
\hline $\begin{array}{c}\text { Blanching } \\
\text { Condition }\end{array}$ & ${\text { TSS }\left({ }^{\circ} \text { Brix) }\right.}$ & $\begin{array}{c}\text { TA (\% Cit- } \\
\text { ric Acid) }\end{array}$ & TSS/TA & pH & BrimA \\
\hline Fresh & $16.1 \pm 0.18^{\mathrm{d}}$ & $1.47 \pm 0.06^{\mathrm{c}}$ & $11.0 \pm 0.39^{\mathrm{a}}$ & $3.22 \pm 0.16^{\mathrm{c}}$ & $13.2 \pm 0.13^{\mathrm{c}}$ \\
Control & $24.9 \pm 0.37^{\mathrm{a}}$ & $4.20 \pm 0.06^{\mathrm{a}}$ & $5.95 \pm 0.16^{\mathrm{b}}$ & $3.39 \pm 0.01^{\mathrm{bc}}$ & $16.6 \pm 0.47^{\mathrm{a}}$ \\
$90^{\circ} \mathrm{C} 30 \mathrm{~s}$ & $21.4 \pm 0.10^{\mathrm{b}}$ & $3.57 \pm 0.09^{\mathrm{b}}$ & $6.01 \pm 0.17^{\mathrm{b}}$ & $3.56 \pm 0.01^{\mathrm{ab}}$ & $14.3 \pm 0.26^{\mathrm{b}}$ \\
$100^{\circ} \mathrm{C} 60 \mathrm{~s}$ & $18.5 \pm 0.15^{\mathrm{c}}$ & $3.40 \pm 0.06^{\mathrm{b}}$ & $5.45 \pm 0.09^{\mathrm{b}}$ & $3.75 \pm 0.01^{\mathrm{a}}$ & $11.7 \pm 0.15^{\mathrm{d}}$ \\
\hline
\end{tabular}

TSS, total soluble solids; TA, titratable acidity. Data presented as means \pm SE in each column followed by different letters are significantly different $(p<0.05)$ according to Fisher's LSD.

Titratable acidity (TA, expressed as \% citric acid) was significantly $(p<0.05)$ increased in the blanched and unblanched arils (Table 3). Unblanched arils had the highest values for TA, followed by arils at $90^{\circ} \mathrm{C}$ for $30 \mathrm{~s}$. Arils blanched at $100{ }^{\circ} \mathrm{C} 60 \mathrm{~s}$ had the least TA values. A significant $(p<0.05)$ change in citric acid with approximately $65 \%$ increase in citric acid was observed for unblanched arils compared to fresh arils, while arils blanched at $90{ }^{\circ} \mathrm{C}$ for $30 \mathrm{~s}$ and $100{ }^{\circ} \mathrm{C}$ for $60 \mathrm{~s}$ increased (58 and $56 \%$ ), respectively, as compared with fresh arils. However, amongst the treatments, blanched arils had the least values of TA compared to unblanched aril. Several studies have reported that organic acids reduction due to high temperature during processing $[41,49]$. The decrease in TA in the blanched arils could be due to the conversion of acid to carbohydrate through an extended time of heat treatment. Our results are in agreement with those reported by Brennard [50], who observed a decrease in TA due to extended drying time in sun-dried fruit. As a result of changes in TSS and TA contents, the values of TSS/TA decreased considerably for both blanched and unblanched arils compared to fresh arils. However, there was no statistical difference amongst the treatments.

Unblanched arils had $5.95 \mathrm{TSS} / \mathrm{TA}$ ratio, while arils blanched at $90{ }^{\circ} \mathrm{C}$ for $30 \mathrm{~s}$ and $100{ }^{\circ} \mathrm{C}$ for $60 \mathrm{~s}$ had TSS/TA ratio of 6.01 and 5.45, respectively. The TSS/TA ratio of blanched pumpkin fruit slices after drying ranged between 3.4 and 4.3 [51], which was lower than the values generated for dried pomegranate arils. TSS/TA value is an important criterion also for evaluating the quality of pomegranate fruit products [1]. Results obtained in this study could be appropriated to the highest proportion of sugar to acid ratio after thermal treatments.

To further investigate the relationship between TSS and TA as a prospective chemical indicator related to flavour, BrimA index was calculated according to Jordan et al. [52] (Table 3). BrimA significantly $(p<0.05)$ increased in unblanched (16.6) and blanched (14.3) arils that were treated at $90^{\circ} \mathrm{C}$ for $30 \mathrm{~s}$, compared to the blanched arils treated at $100{ }^{\circ} \mathrm{C}$ for $60 \mathrm{~s}$ (11.7). The increase in BrimA index for pomegranate dried arils could be as a result of the small amount of acid to sugar ratio observed in this study. Jaya and Das [53] reported that in the calculation of BrimA index, the same numerical changes are observed as a result of the minimal amount of acid than sugar. The $\mathrm{pH}$ of fruit usually characterizes its acidic taste [8]. A significant $(p<0.05)$ increase in dried aril $\mathrm{pH}$ after drying was observed amongst the treatments (Table 3). Higher $\mathrm{pH}$ was observed in blanched arils at $90{ }^{\circ} \mathrm{C}$ for $30 \mathrm{~s}$ and $100{ }^{\circ} \mathrm{C}$ for $60 \mathrm{~s}$ compared to the unblanched arils. The increase in the values of $\mathrm{pH}$ for blanched pomegranate arils could be due to the change in an organic acid to carbohydrate because of the thermal treatment. Workneh et al. [51] reported that changes observed in the $\mathrm{pH}$ of food materials during the period of heat treatment were due to the synthesis of organic acids from carbohydrates.

\subsection{Total Phenolic Content (TPC) and Total Anthocyanin Content (TAC)}

There was a significant $(p<0.05)$ difference in the TPC of dried pomegranate arils (Figure 3). TPC was higher in blanched arils compared to the unblanched arils. Both blanched pomegranate arils $90^{\circ} \mathrm{C}$ for $30 \mathrm{~s}$ and $100{ }^{\circ} \mathrm{C}$ for $60 \mathrm{~s}$ had higher TPC $(148.8$ and $141.7 \mathrm{mg}$ GAE/g DM), respectively than unblanched arils with the least TPC (102.1 mg GAE/g $\mathrm{DM})$. Differences observed in the values of TPC for blanched and unblanched arils in this 
study suggested the level of sensitivity of TPC to temperature during the thermal treatment. Fazaeli et al. [19] noted that bioactive compound such as phenolic and anthocyanin concentration are highly heat-sensitive during thermal processing. Rawson et al. [54] noted that the influence of thermal processing reduces the stability of the bioactive component in food materials. Karaaslan et al. [55], noted that pretreatment resulted in a significant change in the phenolic content of pomegranate arils. A similar trend was also observed in dried tomatoes and apricot [56,57]. The phenomenon is attributed to phenolic-protein complexes in the chloroplasts, resulting from an increased extractability of carotenoids and phenolics from the matrix structure during blanching treatment [57].

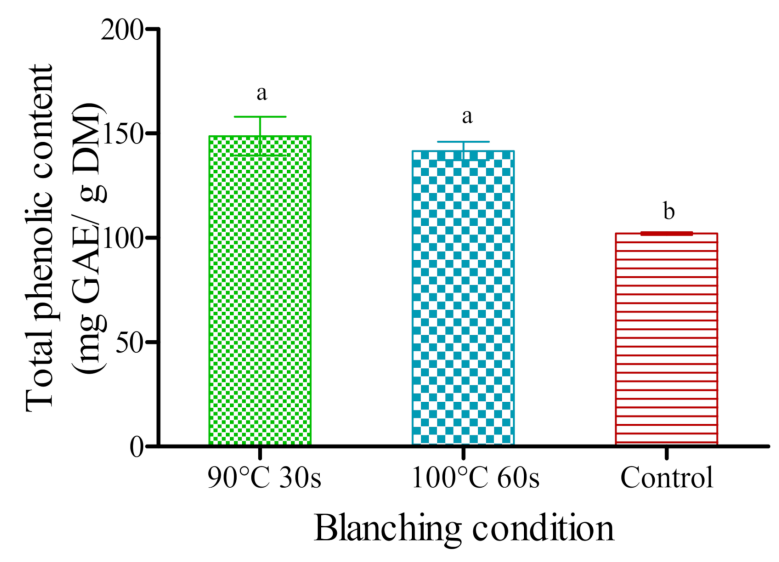

Figure 3. Total phenolic content of dried pomegranate arils cv. Wonderful at different blanching conditions (mg GAE/g DM). (Data presented as means \pm SE. Bars followed by different letter(s) are significantly different $(p<0.05)$ according to Fisher's LSD).

TAC in pomegranate fruit is responsible for the characteristic red colouration $[5,58,59]$. TAC in the blanched arils treated at $90{ }^{\circ} \mathrm{C}$ for $30 \mathrm{~s}$ retained more TAC in comparison with the unblanched arils. Dried pomegranate arils blanched at $90^{\circ} \mathrm{C}$ for $30 \mathrm{~s}$ had the highest TAC (28.6 mg C3gE/g DM), followed by $100{ }^{\circ} \mathrm{C}$ for $60 \mathrm{~s}(24.8 \mathrm{mg} \mathrm{C} 3 \mathrm{gE} / \mathrm{g} \mathrm{DM})$ while unblanched arils (21.8 $\mathrm{mg} \mathrm{C3gE/g} \mathrm{DM)} \mathrm{(Figure} \mathrm{4).} \mathrm{TAC} \mathrm{of} \mathrm{dried} \mathrm{pomegranate} \mathrm{arils}$ blanched at $90{ }^{\circ} \mathrm{C}$ for $30 \mathrm{~s}$ was higher by approximately $23.8 \%$, respectively, compared to the unblanched arils. Sablani et al. [60] reported that blanching treatment before air-drying increased the retention of phenolic and total anthocyanin content in dried berries which is in agreement with the findings from our study. Furthermore, lower TAC observed for unblanched arils could be attributed to greater destruction of phenolic compounds which could change their chemical structure due to the thermal process [61,62].

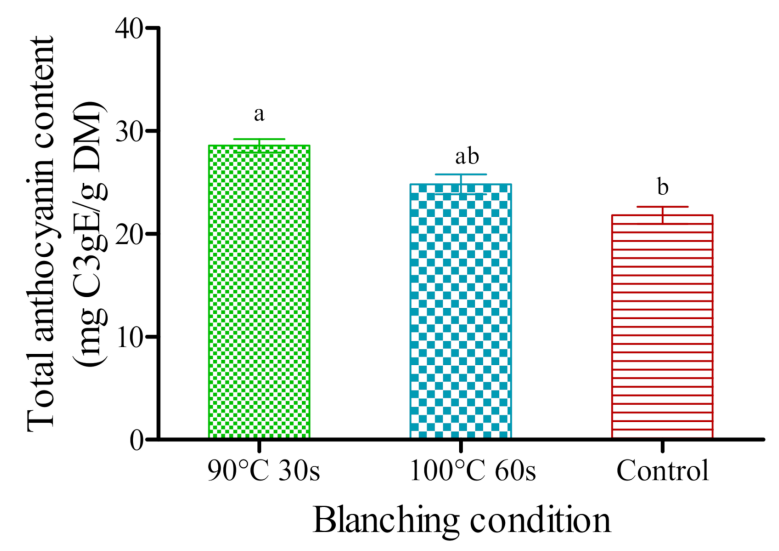

Figure 4. Total anthocyanin content in dried pomegranate arils cv. Wonderful at different blanching conditions. (Data presented as means \pm SE. Bars followed by different letter(s) are significantly different $(p<0.05)$ according to Fisher's LSD). 


\subsection{Antioxidant Capacity}

The RSA of dried pomegranate arils was significantly $(p<0.05)$ higher in blanched arils compared to unblanched arils as presented in (Figure 5a). RSA of dried arils was in the order of $90{ }^{\circ} \mathrm{C}$ for $30 \mathrm{~s}(32.0 \mathrm{mM} \mathrm{TE} / \mathrm{g} \mathrm{DM})>100{ }^{\circ} \mathrm{C}$ for $60 \mathrm{~s}(31.1 \mathrm{mM} \mathrm{TE} / \mathrm{g} \mathrm{DM})$ and unblanched (17.0 mM TE/g DM).
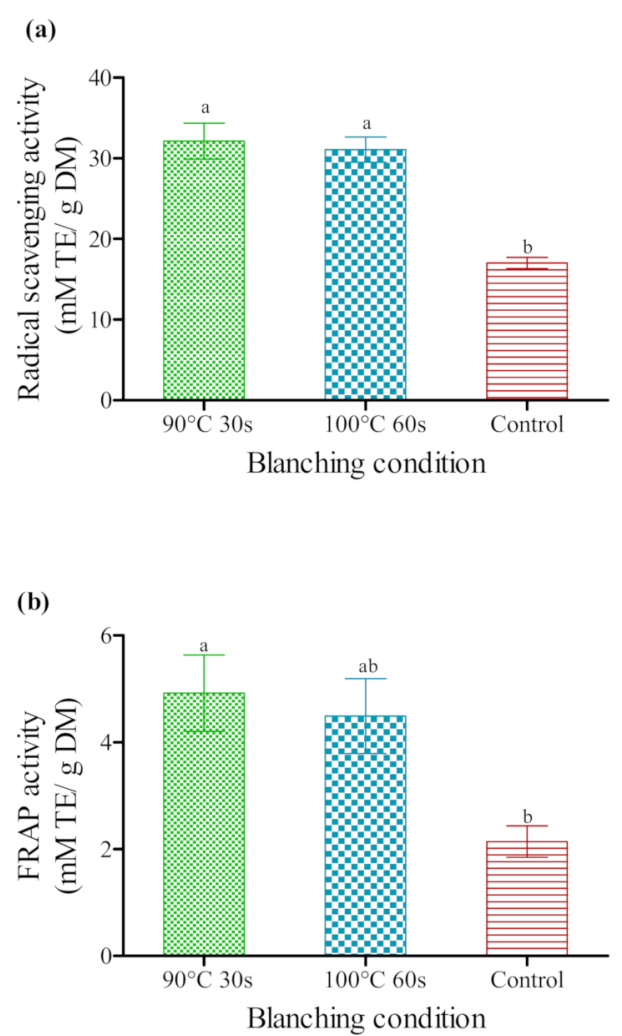

Figure 5. Antioxidant capacity (a) radical-scavenging activity (RSA) and (b) Ferric ion reducing antioxidant power (FRAP) activity of dried pomegranate arils cv. Wonderful at different blanching conditions. (Data presented as means \pm SE. Bars followed by different letter(s) are significantly different $(p<0.05)$ according to Fisher's LSD).

Higher RSA for blanched arils of dried pomegranate arils could be an indication of high retention of antioxidant capacity after thermal treatment. Blanching treatment enhances the retention of the phytochemicals as reported by Karaaslan et al. [55]. Similarly, Sablani et al. [60] reported higher content of phytochemicals in blanched berries before air drying. Among the blanching treatments in the FRAP of dried arils, the highest FRAP was found in the blanched arils at $90^{\circ} \mathrm{C}$ for $30 \mathrm{~s}(4.92 \mathrm{mM} \mathrm{TE} / \mathrm{g} \mathrm{DM})$, while unblanched arils had the least value (2.14 $\mathrm{mM}$ TE/g DM) (Figure $5 b)$. However, the amount of FRAP in blanched arils treated at $100{ }^{\circ} \mathrm{C}$ for $60 \mathrm{~s}(4.49 \mathrm{mM} \mathrm{TE} / \mathrm{g} \mathrm{DM})$ was not statistically $(p<0.05)$ different from unblanched arils. A similar result was reported by Nurhuda et al. [63] that blanching differed insignificantly with respect to the antioxidant capacity of the final product.

\subsection{Multivariate Analysis}

\subsubsection{Principal Component Analysis}

The results show the average of enzyme activity, phenolics, antioxidant capacity, chemical attributes and colour coordinates of blanched and unblanched pomegranate dried arils. The two principal components (F1 and F2) explain $100.0 \%$ of the total data variance (Figure 6). 


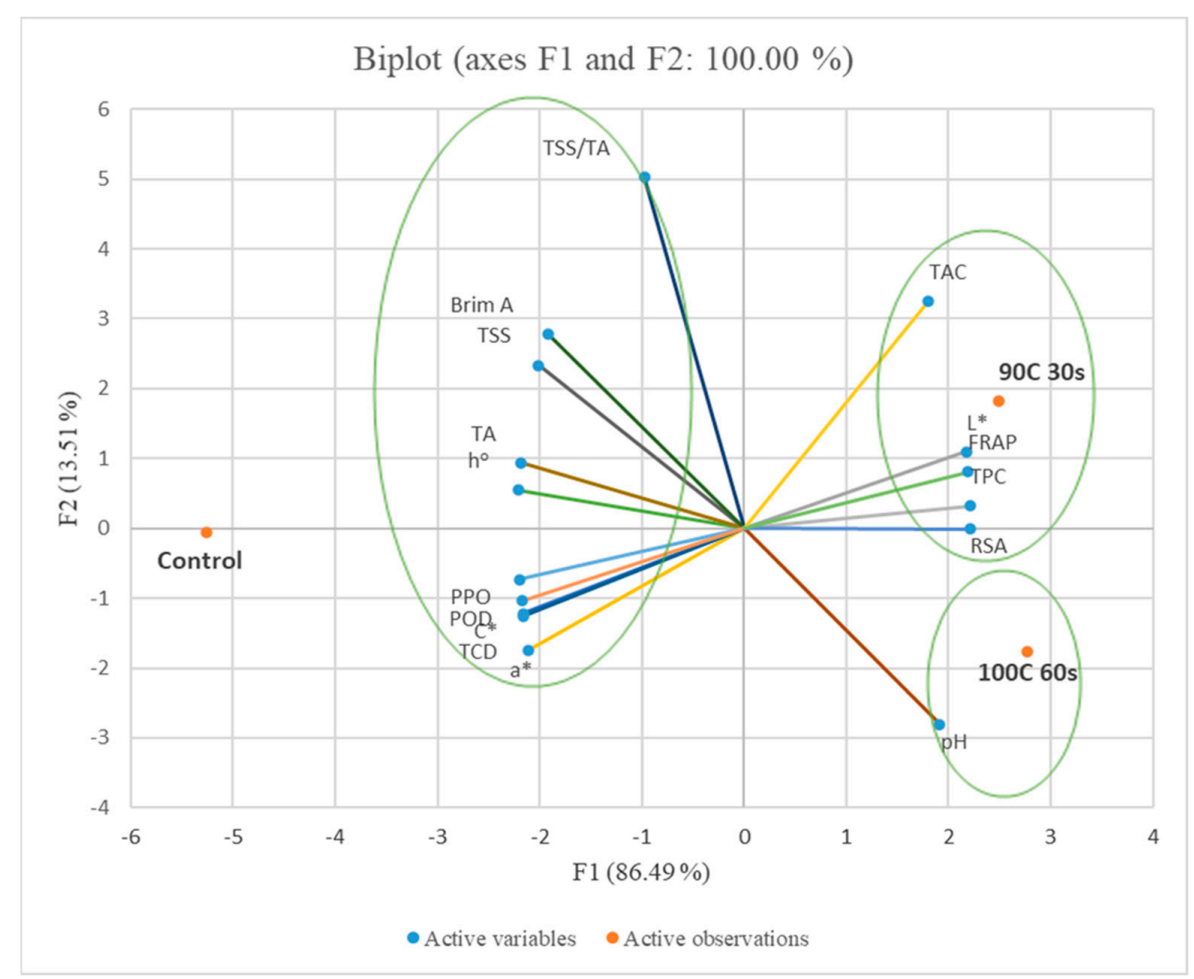

Figure 6. Principal component analysis of the first two factors (F1 and F2) based on physicochemical properties, phenolic content and antioxidant activities of dried pomegranate arils cv. Wonderful at different blanching conditions. $L^{*}$; lightness, $a^{*}$; redness, $C^{*}$; chroma, $h^{\circ}$; hue angle, TCD, total colour difference, RSA, radical scavenging activity; FRAP, ferric reducing antioxidant power, TPC, total phenolic content; TAC, total anthocyanin content; PPO, polyphenol oxidase; POD, peroxidase; TSS, total soluble solids; TA, titratable acidity.

As observed, F1 explained $86.49 \%$ of the total variability among blanched and unblanched dried pomegranate arils while F2 explained only $13.51 \%$ as described in Figure 6 . The observations (Figure 6) indicated that dried arils blanched at $90{ }^{\circ} \mathrm{C}$ for $30 \mathrm{~s}$ and $100{ }^{\circ} \mathrm{C}$ for $60 \mathrm{~s}$ could be associated with $L^{*}, \mathrm{pH}, \mathrm{TPC}, \mathrm{TAC}, \mathrm{FRAP}$, and RSA which had higher positive scores along F1 (Table 4).

Additionally, the higher negative scores (Table 4) along F1 (Figure 6) corresponds to hue, TCD $a^{*}$, chroma $C^{*}$, BrimA, TSS, PPO, POD and TA for the unblanched arils. Also, lower negative scores along F1 were for unblanched arils (associated with TSS/TA). On the other hand, high positive scores (Table 4) along F2 were associated with TSS/TA and TAC for unblanched and blanched arils at $90{ }^{\circ} \mathrm{C}$ for $30 \mathrm{~s}$, respectively, (Figure 6). Likewise, for high negative value along F2 was blanched arils at $100{ }^{\circ} \mathrm{C}$ for $60 \mathrm{~s}(\mathrm{pH})$. Similarly, along the F2, low positive scores (as shown in Figure 6 and Table 4) for unblanched and blanched arils $\left(90^{\circ} \mathrm{C}\right.$ for $\left.30 \mathrm{~s}\right)$ could characterize for hue, TSS, TA, BrimA as well as $L^{*}$, TPC and FRAP, respectively. However, lower negative scores along F2 were for unblanched arils (associated with hue, TCD, PPO, POD, $a^{*}$ and $C^{*}$ ) as well as RSA for blanched arils at $100{ }^{\circ} \mathrm{C}$ for $60 \mathrm{~s}$. The results demonstrated on the PCA showed that blanched and unblanched treatments for pomegranate dried arils have significantly different properties.

\subsubsection{Correlation between Quality Attributes of Dried Arils}

Pearson's correlation was assessed to evaluate the interrelationships between quality attributes of blanched and unblanched arils which includes enzyme activity, chemical and colour attributes as well as phenolic contents and antioxidant capacity (Table 5). Significantly $(p<0.05)$ strong relationships were observed among some of the quality attributes evaluated. TSS and TA showed strong positive correlation $(r=0.966)$. This relationship clearly showed that increase in dried aril TA might also bring about an increase in TSS in blanched arils. Lightness $\left(L^{*}\right)$ showed a strong negative correlation with enzyme 
activities (PPO and POD) $(r=-0.998$ and -1.000$)$, respectively. This relationship indicates that the higher the $L^{*}$ of blanched arils, the lower the enzyme activity. This suggested that blanching halted the effect of browning in aril colour after drying. Another interesting relationship was the strong negative correlation between $a^{*}$ and TAC. This suggests that decrease in the redness of pomegranate arils during drying increases the TAC, as against scientific evidence reported in many studies of pomegranate fruit $[8,64]$ contributing to better red colouration as one of the desired attributes in pomegranate marketing. With regards to the reported health benefits of consuming dried pomegranate arils, high in phenolic compounds [21], it is therefore unsurprising that antioxidant capacity (RSA and FRAP) showed a positive correlation with TPC and TAC. Therefore, the result from our correlation matrix showed plausible retention of antioxidant capacity of blanched arils and also highly dependent on the TPC.

Table 4. Factor loadings and score for the first two principal (F1-F2) components of dried pomegranate arils at different blanching conditions.

\begin{tabular}{ccc}
\hline Loadings & F1 & F2 \\
\hline$L^{*}$ & 0.981 & 0.196 \\
$a^{*}$ & -0.950 & -0.312 \\
$C^{*}$ & -0.976 & -0.218 \\
$h^{\circ}$ & -0.995 & 0.098 \\
TCD & -0.975 & -0.224 \\
pH & 0.865 & -0.501 \\
TSS & -0.909 & 0.417 \\
TA & -0.986 & 0.167 \\
TSS/TA & -0.440 & 0.898 \\
BrimA & -0.867 & 0.498 \\
PPO & -0.992 & -0.130 \\
POD & -0.983 & -0.185 \\
TPC & 0.998 & 0.057 \\
TAC & 0.814 & 0.581 \\
RSA & 1.000 & -0.001 \\
FRAP & 0.989 & 0.145 \\
Scores & & \\
$90^{\circ} \mathrm{C} 30 \mathrm{~s}$ & 2.490 & 1.832 \\
$100{ }^{\circ} \mathrm{C} 60 \mathrm{~s}$ & 2.769 & -1.768 \\
Control & -5.258 & -0.064
\end{tabular}

$L^{*}$, lightness; $a^{*}$, redness; $C^{*}$, chroma; $h^{\circ}$, hue angle; TCD, total colour difference; RSA, radical scavenging activity; FRAP, ferric reducing antioxidant power; TPC, total phenolic content; TAC, total anthocyanin content; PPO, polyphenol oxidase; POD, peroxidase; TSS, total soluble solids; TA, titratable acidity.

Table 5. Pearson's correlation coefficients (r) among the investigated parameters at different blanching conditions.

\begin{tabular}{|c|c|c|c|c|c|c|c|c|c|c|c|c|c|c|c|c|}
\hline Variables & $L^{*}$ & $a^{*}$ & $C^{*}$ & $h^{\circ}$ & TCD & $\mathrm{pH}$ & TSS & TA & TSS/TA & BrimA & PPO & POD & TPC & TAC & RSA & FRAP \\
\hline$L^{*}$ & 1 & & & & & & & & & & & & & & & \\
\hline$a^{*}$ & -0.993 & 1 & & & & & & & & & & & & & & \\
\hline$C^{*}$ & -1.000 & 0.995 & 1 & & & & & & & & & & & & & \\
\hline$h^{\circ}$ & -0.957 & 0.915 & 0.950 & 1 & & & & & & & & & & & & \\
\hline TCD & -1.000 & 0.996 & 1.000 & 0.948 & 1 & & & & & & & & & & & \\
\hline $\mathrm{pH}$ & 0.750 & -0.666 & -0.735 & -0.910 & -0.731 & 1 & & & & & & & & & & \\
\hline TSS & -0.809 & 0.734 & 0.796 & 0.945 & 0.792 & -0.996 & 1 & & & & & & & & & \\
\hline TA & -0.934 & 0.885 & 0.926 & 0.998 & 0.923 & -0.937 & 0.966 & 1 & & & & & & & & \\
\hline TSS/TA & -0.255 & 0.139 & 0.234 & 0.526 & 0.228 & -0.831 & 0.775 & 0.584 & 1 & & & & & & & \\
\hline Brim A & -0.753 & 0.669 & 0.738 & 0.912 & 0.734 & -1.000 & 0.996 & 0.938 & 0.829 & 1 & & & & & & \\
\hline PPO & -0.998 & 0.983 & 0.996 & 0.974 & 0.995 & -0.793 & 0.847 & 0.956 & 0.320 & 0.795 & 1 & & & & & \\
\hline POD & -1.000 & 0.991 & 0.999 & 0.960 & 0.999 & -0.758 & 0.816 & 0.938 & 0.267 & 0.761 & 0.998 & 1 & & & & \\
\hline ТPC & 0.990 & -0.966 & -0.987 & -0.988 & -0.986 & 0.835 & -0.884 & -0.975 & -0.388 & -0.838 & -0.997 & -0.992 & 1 & & & \\
\hline TAC & 0.912 & -0.955 & -0.921 & -0.754 & -0.924 & 0.413 & -0.498 & -0.705 & 0.163 & -0.417 & -0.883 & -0.907 & 0.846 & 1 & & \\
\hline RSA & 0.980 & -0.950 & -0.976 & -0.995 & -0.974 & 0.866 & -0.909 & -0.986 & -0.441 & -0.868 & -0.991 & -0.983 & 0.998 & 0.814 & 1 & \\
\hline FRAP & 0.999 & -0.985 & -0.997 & -0.971 & -0.997 & 0.784 & -0.839 & -0.951 & -0.306 & -0.786 & -1.000 & -0.999 & 0.996 & 0.890 & 0.989 & 1111 \\
\hline
\end{tabular}

Correlation values in bold are significant at $p<0.05$. TPC, total phenolic content; TAC, total anthocyanin content; RSA, radical scavenging activity; FRAP, ferric reducing antioxidant power; PPO, polyphenol oxidase; POD, peroxidase; $L^{*}$, lightness; $a^{*}$, redness; $C^{*}$, chroma; $h^{\circ}$, hue angle; TCD, total colour difference; TSS, total soluble solids; TA, titratable acidity. 


\section{Conclusions}

The effect of blanching treatments $\left(90^{\circ} \mathrm{C}\right.$ for $30 \mathrm{~s}$ and $100{ }^{\circ} \mathrm{C}$ for $60 \mathrm{~s}$ and unblanched sample) on enzyme inactivation and other quality attributes of dried pomegranate arils was studied. Blanching treatment at $90^{\circ} \mathrm{C}$ for $30 \mathrm{~s}$ reduced the polyphenol oxidase and peroxidase enzyme activity significantly compared to those treated at $100{ }^{\circ} \mathrm{C}$ for $60 \mathrm{~s}$. However, unblanched arils significantly increased in TCD, TSS, TA and BrimA of pomegranate dried arils. Lightness $\left(L^{*}\right)$ of dried arils was higher at $90{ }^{\circ} \mathrm{C}$ for $30 \mathrm{~s}$ and corresponded considerably with the total anthocyanin content. Blanching treatment $\left(90^{\circ} \mathrm{C}\right.$ for $\left.30 \mathrm{~s}\right)$ retained more the antioxidant capacity of dried arils. Hence, blanching at a lower temperature $\left(90{ }^{\circ} \mathrm{C}\right)$ and shorter time (30 s) is suggested to optimally maintain the colour and other quality attributes of dried pomegranate arils and therefore recommended. Nevertheless, packaging of dried pomegranate arils with a selection of appropriate nonoxidative materials may provide information on shelf-life prediction and should be further investigated for future research. The evaluated quality components reported in this study provide scientific evidence that could serve as an objective guide in the choice of blanching treatment for dried aril processing.

Author Contributions: Conceptualization, O.A.F.; methodology, A.O.A. and O.A.F.; software, A.O.A.; formal analysis, A.O.A.; investigation, A.O.A.; resources, O.A.F. and U.L.O.; writing—original draft preparation, A.O.A.; writing—review and editing, O.A.F. and U.L.O.; supervision, O.A.F. and U.L.O.; project administration, O.A.F.; funding acquisition, O.A.F. and U.L.O. All authors have read and agreed to the published version of the manuscript.

Funding: This work is based on the research supported by the National Research Foundation (NRF) of South Africa (IUD: 64813 and (IUD: 105722).

Acknowledgments: The financial support of the World Academy of Science and National Research Foundation of South Africa through the award of doctoral scholarship to Adetoro is gratefully acknowledged (IUD: 105483). The opinions, findings and conclusions or recommendations expressed are those of the author(s) alone, and the NRF accepts no liability whatsoever in this regard.

Conflicts of Interest: There is no conflict of interest between the authors.

\section{References}

1. Al-Said, F.A.; Opara, U.L.; Al-Yahyai, R.A. Physico-chemical and textural quality attributes of pomegranate cultivars (Punica granatum) L. grown in the sultanate of Oman. J. Food Eng. 2009, 90, 129-134. [CrossRef]

2. Holland, D.; Hatib, K.; Bar-Yaakov, I. Pomegranate: Botany, horticulture, breeding. Hortic. Rev. 2009, 35, $127-191$.

3. Fawole, O.A.; Makunga, N.P.; Opara, U.L. Antibacterial, antioxidant and tyrosinase-inhibition activities of pomegranate fruit peel methanolic extract. BMC Complement. Altern. Med. 2012, 12, 200. [CrossRef] [PubMed]

4. Pomegranate Association of South Africa (POMASA). Statistics and Information. 2018. Available online: https://www. sapomegranate.co.za/focus-areas/statistics-and-information-2018/ (accessed on 9 November 2019).

5. Fawole, O.A.; Opara, U.L. Changes in physical properties, chemical and elemental composition and antioxidant capacity of pomegranate. cv. Ruby fruit at five maturity stages. Sci. Hortic. 2013, 150, 37-46. [CrossRef]

6. Caleb, O.J.; Opara, U.L.; Witthuhn, C.R. Modified atmosphere packaging of pomegranate fruit and arils: A review. Food Bioprocess Technol. 2012, 5, 15-30. [CrossRef]

7. Espín, J.C.; García-Conesa, M.T.; Tomás-Barberán, F.A. Nutraceuticals: Facts and fiction. Phytochemistry 2007, 68, 2986-3008. [CrossRef] [PubMed]

8. Fawole, O.A.; Opara, U.L. Effects of maturity status on biochemical concentration, polyphenol composition and antioxidant capacity of pomegranate fruit arils. cv. Bhagwa. S. Afr. J. Bot. 2013, 85, 23-31. [CrossRef]

9. Fawole, O.A.; Opara, U.L.; Chen, L. Bio accessibility of total phenolic concentration and antioxidant capacity of pomegranate fruit juice and marc after in vitro digestion. Acta Hortic. 2015, 1079, 285-290. [CrossRef]

10. Opara, U.L.; Al-Ani, M.R.; Al-Shuaibi, Y.S. Physio-chemical properties, vitamin C content, and antimicrobial properties of pomegranate fruit (Punica granatum L.). Food Bioprocess Technol. 2009, 2, 315-321. [CrossRef]

11. Lara, I.; Belge, B.; Goulao, L.F. The fruit cuticle as a modulator of postharvest quality. Postharvest Biol. Technol. 2014, 87, 103-112. [CrossRef]

12. Jahanfar, S.; Fatemian, H.; Hosseini, E.; Asadi, G.H.; Darvish, F. Physicochemical Changes of Impacted Tomatoes with Pendulum Mechanical Forces. IJASR 2011, 2, 39-47.

13. Zaharan, H.; Fawole, O.A.; Opara, U.L. Investigating bruise susceptibility of pomegranate cultivars during postharvest handling. Afr. J. Rural Dev. 2017, 1, 33-39. 
14. Pomegranate Association of South Africa (POMASA). Pomegranate Industry Statistics. Paarl, South Africa, 2012. Available online: http:/ / hortogro.co.za/porfolio/pomegranates/ (accessed on 24 September 2019).

15. Ratti, C. Hot-air and freeze-drying of high-value foods: A review. J. Food Eng. 2001, 49, 311-319. [CrossRef]

16. Kim, T.H.; Hampton, J.G.; Opara, L.U.; Hardacre, A.K.; Mackay, B.R. Effects of maize grain size, shape and hardness on drying rate and the occurrence of stress cracks. J. Sci. Food Agric. 2002, 82, 1232-1239. [CrossRef]

17. Tang, W.; Zhang, M.; Adhikari, B.; Mujumdar, A.S. Effects of preparation and drying methods on the antioxidant activity of enzymatically hydrolyzed porcine placenta hydrolysates. Dry Technol. 2013, 31, 1600-1610. [CrossRef]

18. Alibas, O.I.; Isik, E. Determination of drying parameters in microwave drying of apricot and sweet cherry. In First Stone Fruits Symposium; Ergun, M.E., Burak, M., Eds.; Yalova, Turkey, 2001; pp. 317-328.

19. Fazaeli, M.; Yousefi, S.; Emam-Djomeh, Z. Investigation on the effects of microwave and conventional heating methods on the phytochemicals of pomegranate (Punica granatum) and black mulberry juices. Int. Food Res. J. 2013, 50, 568-573. [CrossRef]

20. Adetoro, A.O.; Fawole, O.A.; Opara, U.L. Effects of pretreatment and drying on the quality attributes of fruit. Acta Hortic. 2017, 1201, 1-6.

21. Thakur, N.S.; Bhat, M.M.; Rana, N.; Joshi, V.K. Standardization of pretreatments for the preparation of dried arils from wild pomegranate. J. Food Sci. Technol. 2010, 47, 620-625. [CrossRef]

22. Meighani, H.; Ghasemnezhad, M.; Bakshi, D. Evaluation of biochemical composition and enzyme activities in browned arils of pomegranate fruits. Int. J. Hortic. Sci. Technol. 2014, 1, 53-65.

23. Arendse, E.; Fawole, O.A.; Magwaza, L.S.; Nieuwoudt, H.H.; Opara, U.L. Evaluation of biochemical markers associated with the development of husk scald and the use of diffuse reflectance NIR spectroscopy to predict husk scald in pomegranate fruit. Sci. Hortic. 2018, 232, 240-249. [CrossRef]

24. Sarpong, F.; Yu, X.; Zhou, C.; Hongpeng, Y.; Bernard, B.; Junwen, U. Influence of anti-browning agent pretreatment on drying kinetics, enzymes inactivation and other qualities of dried banana. Musa ssp. under relative humidity-convective air dryer. J. Food Meas. Charact. 2018, 12, 1229-1241. [CrossRef]

25. Tembo, L.; Chiteka, Z.A.; Kadzere, I.; Akinnifesi, F.K.; Tagwira, F. Blanching and drying period affect moisture loss and vitamin C content in Ziziphus mauritiana Lamk. Afr. J. Biotechnol. 2008, 7, 3100-3106.

26. Doymaz, İ. Effect of citric acid and blanching pretreatments on drying and rehydration of Amasya red apples. Food Bioprod. Process. 2010, 88, 124-132. [CrossRef]

27. Adetoro, A.O.; Tsige, A.A.; Opara, U.L.; Fawole, O.A. Mathematical Modelling of Blanch-Assisted Drying of Pomegranate (Punica granatum) Arils in a Hot-Air Drier. Processes 2020, 8, 611. [CrossRef]

28. Deylami, M.Z.; Rahman, R.A.; Tan, C.P.; Bakar, J.; Olusegun, L. Effect of blanching on enzyme activity, colour change, anthocyanin stability and extractability of mangosteen pericarp: A kinetic study. J. Food Eng. 2016, 178, 12-19. [CrossRef]

29. Maté, J.I.; Zwietering, M.; Van't Riet, K. The effect of blanching on the mechanical and rehydration properties of dried potato slices. Eur. Food Res. Technol. 1999, 209, 343-347. [CrossRef]

30. Maghoumi, M.; Gómez, P.A.; Mostofi, Y.; Zamani, Z.; Artés-Hernández, F.; Artés, F. Combined effect of heat treatment, UV-C and super atmospheric oxygen packing on phenolics and browning related enzymes of fresh-cut pomegranate arils. Food Sci. Technol. 2013, 54, 389-396.

31. Doymaz, I. Drying of pomegranate seeds using infrared radiation. Food Sci. Biotechnol. 2012, 21, 1269-1275. [CrossRef]

32. Jiang, Y.M. Purification and some properties of polyphenol oxidase of longan fruit. Food Chem. 1999, 66, 75-79. [CrossRef]

33. Shah, H.M.S.; Khan, A.S.; Ali, S. Pre-storage kojic acid application delays pericarp browning and maintains antioxidant activities of litchi fruit. Postharvest Biol. Technol. 2017, 132, 154-161. [CrossRef]

34. Pathare, P.B.; Opara, U.L.; Al-Said, F.A.J. Colour measurement and analysis in fresh and processed foods: A review. Food Bioproc. Tech. 2013, 6, 36-60. [CrossRef]

35. Chen, L.; Opara, U.L. Approaches to analysis and modeling texture in fresh and processed foods-A review. J. Food Eng. 2013, 119, 497-507. [CrossRef]

36. Chen, L.; Opara, U.L. Texture measurement approaches in fresh and processed foods-A review. Food Res. Int. 2013, 51, 823-835. [CrossRef]

37. Giri, S.K.; Prasad, S. Drying kinetics and rehydration characteristics of microwave-vacuum and convective hot-air dried mushrooms. J. Food Eng. 2007, 78, 512-521. [CrossRef]

38. Wrolstad, R.E. Colour and pigment analyses in fruit products. In Agricultural Experiment Station; Oregon State University Station Bulletin: Corvallis, OR, USA, 1993; Volume 624.

39. Benzie, I.F.F.; Strain, J.J. The ferric reducing ability of plasma. FRAP as a measure of "antioxidant power" the FRAP assay. Anal. Biochem. 1996, 239, 70-76. [CrossRef]

40. Jaiswal, V.; DerMarderosian, A.; Porter, J.R. Anthocyanins and polyphenol oxidase from dried arils of pomegranate (Punica granatum L.). Food Chem. 2010, 118, 11-16. [CrossRef]

41. Ashebir, D.; Jezik, K.; Weingartemann, H.; Gretzmacher, R. Change in colour and other fruit quality characteristics of tomato cultivars after hot-air drying at low final-moisture content. Int. J. Food Sci. Nutr. 2009, 60, 308-315. [CrossRef]

42. Vega-Gálvez, A.; Lemus-Mondaca, R.; Bilbao-Sáinz, C.; Fito, P.; Andrés, A. Effect of air drying temperature on the quality of rehydrated dried red bell pepper (Capsicum annuum L.). J. Food Eng. 2008, 85, 42-50. [CrossRef] 
43. Dadali, G.; Demirhan, E.; Özbek, B. Color change kinetics of spinach undergoing microwave drying. Dry Technol. 2007, 25, 1713-1723. [CrossRef]

44. Horuz, E.; Maskan, M. Hot-air and microwave drying of pomegranate (Punica granatum) arils. J. Food Sci. Technol. 2015, 52, 285-293. [CrossRef]

45. Adetoro, A.O.; Opara, U.L.; Fawole, O.A. Effect of Hot-Air and Freeze-Drying on the Quality Attributes of Dried Pomegranate (Punica granatum L.) Arils During Long-Term Cold Storage of Whole Fruit. Agriculture 2020, 10, 493. [CrossRef]

46. Adetoro, A.O.; Opara, U.L.; Fawole, O.A. Effect of Carrier Agents on the Physicochemical and Technofunctional Properties and Antioxidant Capacity of Freeze-Dried Pomegranate Juice (Punica granatum) Powder. Foods 2020, 9, 1388. [CrossRef] [PubMed]

47. Beveridge, T.; Weintraub, S.E. Effect of blanching pretreatment on color and texture of apple slices at various water activities. Int. Food Res. J. 1995, 28, 83-86. [CrossRef]

48. Maskan, M. Drying, shrinkage and rehydration characteristics of kiwifruits during hot air and microwave drying. J. Food Eng. 2001, 48, 177-182. [CrossRef]

49. Piga, A.; Pinna, I.; Özer, K.B.; Agabbio, M.; Aksoy, U. Hot air dehydration of figs (Ficus carica L.): Drying kinetics and quality loss. Int. J. Food Sci. 2004, 39, 793-799. [CrossRef]

50. Brennand, C.P. Home Drying of Food; Cooperative Extension Service, Utah State University: Logan, UT, USA, $1994 ;$ p. 330.

51. Workneh, T.S.; Zinash, A.; Woldetsadik, K. Blanching, salting and sun drying of different pumpkin fruit slices. J. Food Sci. Technol. 2014, 51, 3114-3123. [CrossRef]

52. Jordan, R.; Seelye, R.; Mcglone, A. A sensory-based alternative to brix/acid ratio. J. Food Sci. 2001, 55, 36-44.

53. Jaya, S.; Das, H. A vacuum drying model for mango pulp. Dry Technol. 2003, 21, 1215-1234. [CrossRef]

54. Rawson, A.; Patras, A.; Tiwari, B.K.; Noci, F.; Koutchma, T.; Brunton, N. Effect of thermal and non-thermal processing technologies on the bioactive content of exotic fruits and their products: Review of recent advances. Food Res. Int. 2011, 44, 1875-1887. [CrossRef]

55. Karaaslan, M.; Yilmaz, F.M.; Cesur, O.; Vardin, H.; Ikinci, A.; Coskun Dalgic, A. Drying kinetics and thermal degradation of phenolic compounds and anthocyanins in pomegranate arils dried under vacuum conditions. Int. J. Food Sci. Technol. 2014, 49, 595-605. [CrossRef]

56. Dewanto, V.; Wu, X.; Adom, K.K.; Liu, R.H. Thermal processing enhances the nutritional value of tomatoes by increasing total antioxidant activity. J. Agric. Food Chem. 2002, 50, 3010-3014. [CrossRef] [PubMed]

57. Deng, L.Z.; Yang, X.H.; Mujumdar, A.S.; Zhao, J.H.; Wang, D.; Zhang, Q.; Wang, J.; Gao, Z.J.; Xiao, H.W. Red pepper (Capsicum anпиит L.) drying: Effects of different drying methods on drying kinetics, physicochemical properties, antioxidant capacity, and microstructure. Dry Technol. 2018, 36, 893-907. [CrossRef]

58. Gil, G.I.; Sanchez, R.; Marin, J.G.; Artes, F. Quality changes in pomegranate during ripening and cold storage. Eur. Food Res. Technol. 1996, 202, 481-485. [CrossRef]

59. Artés, F.; Tudela, J.; Gil, M. Improving the keeping quality of pomegranate fruit by intermittent warming. Eur. Food Res. Technol. 1998, 207, 316-321. [CrossRef]

60. Sablani, S.S.; Andrews, P.K.; Davies, N.M.; Walters, T.; Saez, H.; Bastarrachea, L. Effects of air and freeze-drying on phytochemical content of conventional and organic berries. Dry Technol. 2011, 29, 205-216. [CrossRef]

61. Lopez, J.; Vega-Ga'lvez, A.; Torres, M.J.; Lemus-Mondaca, R.; QuispeFuentes, I.; Di Scala, K. Effect of dehydration temperature on physico-chemical properties and antioxidant capacity of goldenberry (Physalis peruviana L.). Chil. J. Agric. Res. 2013, 73, 293-300. [CrossRef]

62. Süfer, Ö.; Palazoğlu, T.K. Microwave-Vacuum drying of pomegranate arils (Punica granatum L. cv. Hicaznar): Effect on quality and nutrient content. J. Food Process. Preserv. 2019, 43, 14085. [CrossRef]

63. Nurhuda, H.H.; Maskat, M.Y.; Mamot, S.; Aiq, J.; Aminah, A. Effect of blanching on enzyme and antioxidant activities of rambutan. Nephelium lappaceum. peel. Int. Food Res. J. 2013, 20, 1725-1730.

64. Arendse, E.; Fawole, O.A.; Opara, U.L. Effects of postharvest storage conditions on phytochemical and radical-scavenging activity of pomegranate fruit (cv. Wonderful). Sci. Hortic. 2014, 169, 125-129. [CrossRef] 